\title{
Research Paper Trends in agricultural and non-agricultural wages in Karnataka state
}

\author{
Deepa G. Wader and G. N. Kulkarn
}

See end of the paper for authors' affiliations

Correspondence to :

Deepa G. Wader

Department of Agricultural

Economics, College of

Agriculture (UAS),

Dharwad (Karnataka)

India

Email: deepawader@gmail. com

\section{Paper History :}

Received : 18.12.2019;

Revised : 14.07.2020

Accepted : 15.08 .2020
ABSTRACT : The present study attempts to analyse trends in growth in agricultural and nonagricultural labourer across the districts of Karnataka state. For the study secondary data of twentyfive years for the period from 1991 to 2015 was collected from the Directorate of Economics and statistics, Karnataka state. Growth rate of both male and female average daily wages are significantly positive, which indicated increasing wage trend in both dry land and irrigated conditions in different study districts. Compound annual growth rate of daily wages of male agricultural labourers in dry land and irrigated condition is comparatively high in Dharawad, Raichur and Hassan districts. The compound growth rates in wages across districts in dry and irrigated regions for female agricultural workers remained almost the same between 9.1 to 13.1 per cent. It could be, therefore, ascertained that there has been only a marginal changes in the wages across the districts of the state. Growth rate in daily wages for carpenter, blacksmith and mochis in different districts ranged between 7.2 per cent to 12.7 per cent per annum. Comparison of the growth rates of agricultural labourer and non-agricultural labourer, showed that agricultural wages grew at a faster rate than non-agricultural wages across the districts. The daily actual wages of both male and female agricultural labourer were compared with minimum wage price in the state revealed that, more than 75 per cent of districts in state are paying below the minimum wages announced for male agricultural labourer, whereas for female agricultural labourer in all the districts of the state showed less than minimum wages.

KEY WORDS : Agricultural, Non-agricultural labourer, Compound growth rate, Minimum wages

How To Cite This PAper : Wader, Deepa G. and Kulkarn, G.N. (2020). Trends in agricultural and nonagricultural wages in Karnataka state. Internat. Res. J. Agric. Eco. \& Stat., 11 (2) : 185-190, DOI : 10.15740/ HAS/IRJAES/11.2/185-190. Copyright@2020:Hind Agri-Horticultural Society. 